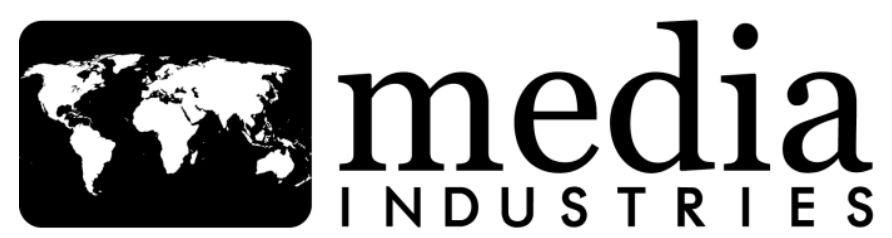

\title{
The Industrialization and Globalization of China's Musical Theater
}

\author{
Shin Dong Kim ${ }^{1}$ \\ Hallym University \\ kimsd [AT] hallym.ac.kr
}

\begin{abstract}
:
After the successful development and spread of Korean media products, such as television dramas, films, pop music, and so forth, major players in the industry are actively seeking ways to globalize their business practices from market research to product delivery. Globalization of the media business, however, provides few working models or theories. Unlike other business operations, media production and consumption involve cultural and political filtering processes that are not easily translated into different social contexts. In the last decade, the development of the musical theater business in China, in cooperation with Korean musical companies, provides an interesting case study of success within the cultural industries. Combining Korean technology and expertise with the rising Chinese-culture market, global musicals were reborn in local productions with notable financial successes. This short essay explores the recent development of musical ventures in Shanghai from the perspective of global collaboration. The political will of the Chinese government, rising and maturing cultural markets in the megacities of China, Korean performing arts companies' desire to globalize, and the local production of global joint ventures are key elements examined.
\end{abstract}

Keywords: Globalization, Marketing, Music, Nationalism, Political Economy

The Broadway musical Chicago was widely advertised before coming to Shanghai for the first time in February 2014, hitting twelve stages in thirteen days. The price of tickets ranged from $800 \mathrm{RMB}$ to $80 \mathrm{RMB}$, compared to movie ticket prices averaging 30 to $40 \mathrm{RMB}$. Many expected tickets to sell out before the show opened. To the great disappointment of musical fans in Shanghai, the show never materialized. The China tour began in the southern city of Fuzhou in December 2013, but the performing team from Broadway hastily left the city for New York after a contentious initial period of production. According to the New York team, the local theater's technology was never properly prepared, and the Chinese partner was unable to resolve the problem in time for the tour to continue. In addition to advance ticket sales, performances at other theaters were already scheduled, which only increased the financial losses associated with the tour.

Although musicals are a relatively new form of entertainment in Shanghai, and in China in general, they have achieved handsome success with Chinese audiences in recent years. In the 
fall of 2013, The Phantom of the Opera's London team toured China and attracted a robust audience in Shanghai, seemingly demonstrating that the local musical market is expanding. Over the last decade, the market has grown with a good number of potential consumers of high-end entertainment, but business practices and technological capabilities in the domestic culture industry have not kept pace with the quickly developing demand.

The Western musical is not a total stranger to young, wealthy audiences in the global city of Shanghai. The Phantom of Opera came to the city eight years ago and enjoyed a good response. But foreign musicals have suffered from a fundamental language barrier that has limited their popularity to big cities and a modest number of affluent audiences. The first attempt to adapt this new entertainment model into a fully localized production was Mamma Mia in 2011. It was staged 188 times in three major cities: Beijing, Shanghai, and Guangzhou. The successful launch of the show in these big cities paved the way for 97 additional performances in local cities throughout the following year. The show returned to the three big cities again in 2013, with 124 stagings and will likely continue its run for several years. Encouraged by the success of Mamma Mia, another classic musical, Cats, followed in 2012, with 159 performances in Beijing, Shanghai, and Guangzhou, and 71 in local cities throughout 2013. The original producer in London licensed both productions. A well-organized local producer, the United Asia Live Entertainment (UALE), which represented a joint venture between Korean media company CJ and the Chinese government, were behind the successful introduction of these locally produced musicals into the Chinese market.

Some brief context regarding the development of the music business in China reveals a few fundamental facts. Some Chinese cities are ready for the musical entertainment business. However, although musicals can make a profit in China, they are not always successful. There are more limits placed on foreign musicals than on local productions. The local skills and technological expertise involved in producing musicals do not conform to global business practices. Taking a joint-venture approach, which involves combining foreign musicals with local production practices, seems to work well when the local experience in musicals is limited. In many parts of the world, local productions and foreign tours are the two main types of musical productions. When there is no local capacity to produce musicals, tours by foreign visiting performers are often the only option for this type of entertainment, even if these tours often come up against cultural barriers.

From a slightly different point of view, foreign and local musical productions represent different types of what might be called business globalization. The simplest form of business globalization involves the export of finished goods and services. Foreign tours of musical productions fall into this category. A more developed form of business globalization often establishes the circuit of production, distribution, and consumption through a locally dependent process. UALE entered the musical market by combining musical production technologies and management from Korea with Chinese staffing and marketing. A team of musical production experts arrived in Shanghai and recruited Chinese actors and actresses, who were then trained by Korean producers. All content was translated through collaboration between the Korean team and Chinese crew. After the initial production, the Korean team left, and the Chinese staff and crew managed successive productions. In this way, the collaboration also resulted in technology transfers. UALE, the Korean partner, introduced different types of stories, shows, and levels of production technology into the local industry. 
Paralleling the economic development of China, the media and culture industry has experienced remarkable growth in the last decade. In contrast with its success with material goods, China found it difficult to become a global exporter in the area of cultural goods and services. If the growth of the Chinese economy has been dependent on an export-led development strategy, growth in the culture industry has depended mainly on domestic consumption. In a way, this is a natural outcome of the country's rising economic development and prosperity. China's economic development in the last couple of decades following Deng Xiaoping's open and pragmatic policy has produced a thick layer of affluent, middle-class consumers. These were China's new rich, who were able and ready to spend on cultural consumption. The development of a market economy also promoted the expansion of the advertising industry and eventually a competitive commercial media system. Television, film, magazines, books, arts, performances, and all other forms of cultural consumption were initially conceived of as simply the fruits of economic development. However, the notion of "culture as industry" entered the nation's political process in the period surrounding the 2008 Beijing Olympic Games.

In 2007, the Seventeenth National Congress of the Communist Party of China announced that the state would promote "great cultural development and prosperity of socialism," based on Chinese national culture, and hoped to become a leading country in the domain of global culture. The globalization of Chinese culture became a political goal linked to China's rising soft power. The new policy included structuring the culture industry according to a marketeconomy system. Led by the Ministry of Culture, this process centered on providing public funding for big state corporations, such as CCTV and the China Arts and Entertainment Group. The state also actively engaged in globalizing Chinese culture through expanding cultural exchanges, establishing overseas posts, and developing foreign cultural partnerships. The rapid expansion of Confucius Institutes to universities around the world and the active proliferation of CCTV to Africa and other parts of the globe were also part of this process.

In 2009, the State Council of the PRC published a "culture industry promotion plan" that aimed at

- developing a new growth engine for restructuring the Chinese industrial structure through the promotion of the culture industry;

- speeding up major projects and strengthening the overall competitiveness, size, and power of culture industry;

- converting state companies involved in the cultural industry into stock companies with diverse types of ownership structures;

- lowering the barriers to entry in order to actively attract foreign capital; and

- expanding the performing arts into a "live entertainment industry," under the Ministry of Culture.

But the expansion of the Chinese culture industry is linked to politically delicate issues. The Chinese government's efforts to open the cultural industry market have been impeded by the old and obstinate ideological systems. On the one hand, the Chinese government aims to promote the development of a globally competitive culture industry. On the other hand, the ruling Communist Party is afraid of exposing the country to "too much" foreign culture. A protective, paternalistic state stands between the task of industrial development and ideological safeguards. However, the development of the culture industry requires increased interactions and transactions with foreign players who could provide advanced content and technology. As is well known, Facebook does not work in China, and Google has experienced many 
operational challenges. Media are generally under government censorship and the administration tightly controls the supply of foreign cultural content. In these circumstances, industrialization, let alone globalization, of culture is never a simple task. Nevertheless, it is noteworthy that the Chinese government is moving to admit that "culture" is no longer subject to political monopoly. The country is opening its cultural market quickly and widely to the rest of the world and also wants to become a prominent exporter of cultural commodities.

While the Chinese state was busy making plans to develop its culture industry, on the other side of the Yellow Sea social and political discourses about the cultural industries have attracted much Korean media attention. After the successful development and spread of Korean media products such as television dramas, films, and pop music among countries in Asia, major players in the Korean industry have been actively seeking ways to globalize their business practices, from market research to product delivery. Globalization of media businesses, however, provides few models or theories that can be readily recycled. Unlike other business operations, media production and consumption involve cultural-filtering processes that are not easily translated into different social contexts. A global division of labor, for instance, is one of the typical methods of business globalization in many industries ranging from automobile production to beer breweries. In the areas of film production and distribution, a global division of labor has been widely used, but with limited success in most cases. The global film industry's methods of producing and exporting product have changed little after a century of global operation. The global film industry has widely pursued and adopted coproductions, joint investments, and distribution partnerships, but these efforts are minor in comparison to other industry sectors. Musicals, films, and most other genres of the culture industries follow similar patterns.

For the Korean culture businesses, China is a difficult target. It is difficult to deal with the Chinese government, especially for media and cultural businesses. Television programs and films are under the tight control of the Communist Party. Foreign imports are kept to a minimum, as they are viewed as cultural-imperialist products. China is the largest consumer of Korean media culture, from television shows to K-pop. The problem is that most of this consumption is the result of illegal circulation on the internet and via copies of DVDs purchased on the streets. China will only provide returns for Korean media actors if a portion of this illegal flow can be channeled into legal transactions.

Fortunately, the situation seems to be turning a corner, as China seeks industrialization in the media and culture arena. For Korean businesses, this has presented an opportunity to expand their deals with Chinese partners. In the case of the musical, for instance, the Chinese Ministry of Culture initially contacted the world-renowned British theatrical producer Cameron Mackintosh regarding a joint venture. But this attempt never succeeded, as both parties could not agree on the prospective partner's idea of the joint venture. Oftentimes, global business collaborations with Chinese partners, who insist on the Chinese way of controlling shares, create difficulties for foreign firms. Yet this failed collaboration with Mackintosh opened an unexpected opportunity for a Korean firm. Under pressure to develop the culture industry, and responding in part to competition from the Chinese State Administration of Radio, Film, and Television (SARFT), which controls most of media entertainment and thus industrialized mass culture, the Ministry of Culture continued to pursue the expansion of the Chinese musical market. After failed collaboration attempts with the British, and recognizing the significant 
growth of the Korean musical market over the last decade, the Ministry reached out to Korean partners after the Beijing Olympic Games in 2008.

The growth of the Chinese musical market in many ways parallels what happened in Korea. Common factors are readily observable and include economic growth and rise of disposable personal income; demand for high-level entertainment other than television and film; growing cultural consumption by young single women in their twenties and thirties; the emergence of musical fandom; and the availability of blockbuster franchises such as The Phantom of Opera, Mamma Mia, and Cats. Significantly, China is in the midst of a theater-construction boom. After this infrastructure is complete, China will not be far from Korea in terms of making the musical a successful popular pastime.

There are, however, a few critical differences between the two countries in terms of their ventures into musical theater. Chinese technology of musical production and management lags behind Korea. The political sensitivity of cultural production in China is a second critical difference. Nevertheless, both parties seem to view the case of UALE as a successful international collaboration that promises positive developments within the Chinese musical market. On the Korean side, creating a reliable window through which Korean performing arts businesses can enter the Chinese market was a meaningful gain. To the Chinese, the Korean partner brings accumulated experience and resources to the Chinese industry in the form of new and original content, workforce expertise and training (e.g., creators, designers, and technical staff), and new equipment (e.g., lighting, stage, and sound).

The globalization of the cultural industry comes in many different forms. Wider distribution and consumption of cultural content used to be and still is the most common form of cultural globalization. Joint production is a more complicated form of global collaboration. While China's ambitious plan for the industrialization and globalization of culture is still new, it promises to encourage the country to lower the protective wall surrounding its cultural and political domain to the rest of the world. Musicals are not much different than television, film, or music productions, but they are less politically loaded. Therefore, it might be easier for the Chinese government to start with musicals as a less politically controversial cultural area and then move on to other fields. ${ }^{2}$

1 Shin Dong Kim has taught media globalization, industry, and policy at Hallym University in Korea since 1998. His research interests range from the political economy of media to media policy, mobile communication, and global media culture. Recently he taught short courses on East Asian media globalization in Shanghai, Hong Kong, Taiwan, and Beijing. He also taught on Korean cinema and its media system in Paris during his visiting assignment at Sciences Po in Paris, France. He serves as a coordinator for the global programs for the School of Communication, and advises industry and government.

2 As this publication goes to press, Chinese television stations are busy reproducing Korean television program formats. Because the government restricts the direct import of Korean programs and the original programs are already widely available on the internet, local stations have quickly picked up a new business strategy of Koreanformat purchasing and reproduction, often coupled with importing the production technologies. This is a small but very noticeable development in television production 
practices, and it promises to bring about significant change to China's central entertainment medium.

\section{(cc) BY-NC-ND}

Copyright (C) 2015 (Shin Dong Kim). Media Industries is an open-access, peer-reviewed, online academic journal. As such, we aim to participate in the open exchange of information. This work is licensed under a Creative Commons Attribution Noncommercial No Derivatives (by-nc-nd) License. Under this license, this work is available for sharing and noncommercial distribution provided the appropriate attribution is given. 